\title{
Paenibacillus lutrae sp. nov., A Chitinolytic Species Isolated from A River Otter in Castril Natural Park, Granada, Spain
}

\author{
Miguel Rodríguez ${ }^{1}$, José Carlos Reina ${ }^{1}$, Victoria Béjar ${ }^{1,2}$ and Inmaculada Llamas ${ }^{1,2, *}$ \\ 1 Department of Microbiology, Faculty of Pharmacy, University of Granada, 18071 Granada, Spain; \\ miguelrg@correo.ugr.es (M.R.); josecreina@ugr.es (J.C.R.); vbejar@ugr.es (V.B.) \\ 2 Institute of Biotechnology, Biomedical Research Center (CIBM), University of Granada, 18100 Granada, Spain \\ * Correspondence: illamas@ugr.es
}

Received: 5 November 2019; Accepted: 29 November 2019; Published: 2 December 2019

\begin{abstract}
A highly chitinolytic facultative anaerobic, chemoheterotrophic, endospore-forming, Gram-stain-positive, rod-shaped bacterial strain $\mathrm{N} 10^{\mathrm{T}}$ was isolated from the feces of a river otter in the Castril Natural Park (Granada, Spain). It is a slightly halophilic, motile, catalase-, oxidase-, ACC deaminase- and $\mathrm{C} 4$ and $\mathrm{C} 8$ lipase-positive strain. It is aerobic, respiratory and has a fermentative metabolism using oxygen as an electron acceptor, produces acids from glucose and can fix nitrogen. Phylogenetic analysis of the $16 \mathrm{~S}$ rRNA gene sequence, multilocus sequence analysis (MLSA) of $16 \mathrm{~S}$ rRNA, gyrB, rec $A$ and $r p o B$, as well as phylogenomic analyses indicate that strain $\mathrm{N}^{2} 0^{\mathrm{T}}$ is a novel species of the genus Paenibacillus, with the highest $16 \mathrm{~S}$ rRNA sequence similarity (95.4\%) to P. chitinolyticus LMG $18047^{\mathrm{T}}$ and $<95 \%$ similarity to other species of the genus Paenibacillus. Digital DNA-DNA hybridization (dDDH) and average nucleotide identity (ANIb) were $21.1 \%$ and $<75 \%$, respectively. Its major cellular fatty acids were anteiso- $C_{15: 0}, C_{16: 0}$, and iso- $C_{15: 0}$. $G+C$ content ranged between $45 \%-50 \%$. Using $16 \mathrm{~S}$ rRNA phylogenetic and in silico phylogenomic analyses, together with chemotaxonomic and phenotypic data, we demonstrate that type strain $\mathrm{N} 10^{\mathrm{T}}\left(=\mathrm{CECT} 9541^{\mathrm{T}}=\mathrm{LMG}\right.$ $30535^{\mathrm{T}}$ ) is a novel species of genus Paenibacillus and the name Paenibacillus lutrae sp. nov. is proposed.
\end{abstract}

Keywords: Paenibacillus lutrae; river otter; new species; chitinolytic activity

\section{Introduction}

Chitins, the second most abundant polymers after cellulose, are widely found in nature. They are present in arthropod, nematode, and mollusc integuments, in insect gut linings, fungal cell walls, some algae and in protozoan cysts [1]. Given their wide distribution, chitin degraders could be used effectively to combat pathogenic organisms, of which chitin is an essential component. Chitin can be degraded by hydrolytic enzymes, called chitinases (EC 3.2.1.14), which are produced by several viruses, as well as prokaryote and eukaryote organisms [2,3].

The principal bacterial groups capable of degrading chitin belong to the genera Cytophaga, Flavobacterium [4,5], and Actinomyces [6,7]. Other groups, which are also active chitin degraders, include species of the genera Bacillus, Paenibacillus, Serratia, Sporosarcina, Exiguobacterium [6-10], Aeromonas [11], Pseudomonas [12], Stenotrophomonas [13], Streptomyces, Arthrobacter and Micromonospora [14-19].

Chitin-degrading bacteria mainly inhabit marine habitats, where they account for approximately $1 \%$ of all prokaryotes $[20,21]$. These bacteria can also be isolated from soil and other habitats such as the digestive system of certain mammals and insects [22,23] with chitin digestion is proven to require bacterial symbiosis. The biotechnological applications of chitinolytic microorganisms and their enzymes include chitin bioconversion in fertilizer compounds; in insecticides, nematicides, and 
fungicides used in agricultural pest control; as well as for biodegradable materials, such as contact lenses, artificial skin, and sutures, in human health care [24-27].

Paenibacillus species were originally assigned to the genus Bacillus, first described in 1872, and the type species was B. subtilis. A phylogenetic analysis of Bacillus species in 1992 based on 16S rRNA sequencing segregated the species into at least five distinct clusters, one of which was reassigned to the novel genus Paenibacillus [28]. Members of this genus, currently composed of over two hundred species, have the following characteristics: ellipsoidal spores in swollen sporangia, $G+C$ content ranging from 39 to $54 \mathrm{~mol} \%$, 12-methyltetradecanoic acid (anteiso- $\mathrm{C}_{15: 0}$ ) as the major cellular fatty acid, and menaquinone-7 (MK-7) as the principal isoprenoid quinone. The chitinolytic species are P. alvei [29], P. chitinolyticus [30,31], P. dendritiformis [32], P. elgii [33], P. larvae [34], P. macerans [35,36], P. mucilaginosus [37], P. pasadenensis [38], P. pulvifaciens [39], P. timonensis [40], and P. xylanilyticus [41].

Our research group was interested in selecting new chitin-degrading bacteria with potential biotechnological applications. Given that river otters are known to contain Firmicutes as the dominant group in their intestinal microbiota [42] and that river crabs are part of their diet, we analyzed the microbiota present in the feces of river otters living in the Castril Natural Park in Granada, Spain. In this study, we describe a new chitin-degrading species isolated from the feces of a river otter and demonstrate that the intestinal microbiota of crustacean-eating otters is a good source of bacteria with biotechnological potential as chitinase producers.

\section{Material and Methods}

\subsection{Bacterial Strains and Growth Conditions}

Strain $\mathrm{N} 10^{\mathrm{T}}$ was isolated from the feces of a river otter in Castril Natural Park, Granada, Spain $\left(37^{\circ} 52^{\prime} 00^{\prime \prime} \mathrm{N} 2^{\circ} 45^{\prime} 58^{\prime \prime} \mathrm{W}\right)$. One gram of feces was suspended in $0.9 \%(w / v)$ saline solution and heated to $80^{\circ} \mathrm{C}$ for $20 \mathrm{~min}$ to select sporulated bacteria. $0.1 \mathrm{~mL}$ of the sample was then plated on Luria-Bertani (LB) agar medium and incubated at $28{ }^{\circ} \mathrm{C}$ for 7 days. The different isolated colonies were subsequently plated and purified on the same medium. Paenibacillus polymyxa CECT $155^{\mathrm{T}}$ and Paenibacillus chitinolyticus LMG $18047^{\mathrm{T}}$ were used as reference strains for comparative purposes. All strains were maintained and cultivated in LB medium at $28^{\circ} \mathrm{C}$ unless otherwise stated.

\subsection{Phenotypic Characterization}

Minimal standards for describing new taxa of aerobic, endospore-forming bacteria as recommended by Logan et al. [43] were used in the description of type species Paenibacillus. The morphology, size, and pigmentation of colonies were observed on LB agar medium after $48 \mathrm{~h}$ of incubation at $28{ }^{\circ} \mathrm{C}$. Cell morphology, flagella type, size, spore morphology and position in the sporangia were determined by transmission electron microscopy (TEM) after negatively staining cells with $2 \%(w / v)$ uranyl acetate. Motility was observed using log phase culture according to the hanging drop method. Oxidase activity [44] and catalase were also determined.

Growth range and optimum growth were determined in LB broth medium at different $\mathrm{NaCl}$ concentrations ranging from $0 \%$ to $10 \%(w / v)$ in 1.0 intervals at $\mathrm{pH} 7$. The $\mathrm{pH}$ growth range and optimum were determined in LB broth medium. $\mathrm{pH}$ was adjusted from 4 to 11 in $1.0 \mathrm{pH}$ unit intervals, using the following buffer systems: $0.1 \mathrm{M}$ citric acid/0.1 M sodium citrate ( $\mathrm{pH}$ 4.0-5.0,); $0.1 \mathrm{M}$ $\mathrm{KH}_{2} \mathrm{PO}_{4} / 0.1 \mathrm{M} \mathrm{NaOH}$ (pH 6.0-8.0); 0.1 M NaHCO $3 / 0.1 \mathrm{M} \mathrm{Na}_{2} \mathrm{CO}_{3}$ (pH 9.0-10.0); $0.2 \mathrm{M} \mathrm{KH}_{2} \mathrm{PO}_{4} / 0.1 \mathrm{M}$ $\mathrm{NaOH}$ (pH 11.0) [45]. Optical density at $600 \mathrm{~nm}$ was monitored using a spectrophotometer to determine bacterial growth. The temperature range and optimum for growth were determined at 15, 22, 28, 37 , and $45{ }^{\circ} \mathrm{C}$ on LB agar plates. Anaerobic growth capacity was evaluated on LB agar medium by incubation in hermetic jars using the Gas Pak anaerobic system (BBL) to generate an anaerobic atmosphere over a one-week period. $\mathrm{H}_{2} \mathrm{~S}$ production was tested in liquid LB medium supplemented with $0.01 \%(w / v)$ L-cysteine using a strip of paper impregnated with lead acetate and placed in the neck of the tube as an indicator [46]. To assay nitrate reduction, $0.2 \%(w / v) \mathrm{KNO}_{3}$ was added to the $\mathrm{LB}$ 
medium. Nitrite was detected with $\alpha$-naphthylamine/sulfanilic acid reagents, and gas production was detected in inverted Durham tubes [47]. Indole production was determined using peptone broth as the growth medium [48], while the methyl-red and Voges-Proskauer tests used peptone supplemented with $0.5 \% w / v$ glucose [49]. The use of citrate as sole carbon source was tested in Simmons medium [50].

Hydrolysis of chitin, casein, cellulose, DNA, Tweens ${ }^{\circledR} 20$ and 80; and production of acid and alkaline phosphatase, lecithinase, lipase, and hemolysine; and the liquefaction of gelatine were also performed [50]. Growth on MacConkey agar medium was assessed after 7 days of incubation. Nitrogen-fixing capacity was tested in Burk medium by following the protocol described by Stella and Suhaimi [51]. The 1-aminocyclopropane-1-carboxylic acid (ACC) deaminase enzyme was detected according to the protocol described by Poonguzhali et al. [52]. Siderophore production was tested using the chromeazurol sulphonate (CAS) method [53]. Other biochemical characteristics were analyzed using API 50CH, API 20NE and API ZYM, according to the manufacturer's instructions.

The diffusion agar method was used to assay antimicrobial susceptibility [54]. The following antimicrobial discs were tested: ampicillin $10 \mu \mathrm{g}$, chloramphenicol $30 \mu \mathrm{g}$, kanamycin $30 \mu \mathrm{g}$, nalidixic acid $30 \mu \mathrm{g}$, rifampicin $2 \mu \mathrm{g}$, streptomycin $10 \mu \mathrm{g}$, gentamicin $10 \mu \mathrm{g}$, neomycin $30 \mu \mathrm{g}$, novobiocin $30 \mu \mathrm{g}$, penicillin G $10 \mu \mathrm{g}$, tetracyclin $30 \mu \mathrm{g}$, and trimethoprim/sulfamethoxazole 1.25/23.75 $\mu \mathrm{g}$.

\subsection{Chemotaxonomic Analysis}

The cellular fatty acids, polar lipids, respiratory quinones and the diamino acid of the cell-wall peptidoglycan were analyzed at the German Collection of Microorganisms and Cell Cultures (DSMZ) according to the protocol described by Tindall et al. [55], Tindall [56,57] and Schumann [58], respectively. For these analyses, the cell mass of $\mathrm{N} 10^{\mathrm{T}}$ strain, P. chitinolyticus $\mathrm{LMG} 18047^{\mathrm{T}}$ and P. polymyxa CECT $155^{\mathrm{T}}$, was obtained after growing $24 \mathrm{~h}$ at $28^{\circ} \mathrm{C}$ in TSB medium.

\subsection{Phylogenetic $16 S$ rRNA Gene Analysis}

Genomic DNA was isolated by using the X-DNA purification kit (Xtrem Biotech S.L., Granada, Spain). The 16S rRNA gene was amplified with the aid of universal bacterial primers 16F27 and 16R1488. The PCR product was purified and cloned into the $\mathrm{pGEM}^{\circledR}{ }_{-} \mathrm{T}$ vector (Promega, Wisconsin, USA). Direct sequencing of PCR-amplified DNA was determined using an ABI PRISM DyeTerminator Cycle Sequencing Ready Reaction kit (Perkin-Elmer, Massachusetts, USA) and an ABI PRISM 377 sequencer (Perkin-Elmer) according to the manufacturer's instructions. The DNA sequence obtained was compared to reference 16S rRNA gene sequences available in GenBank and EMBL databases obtained from the NCBI Genome Database using BLASTN software [59] and the EzBioCloud server (https://www.ezbiocould.net) [60]. The phylogenetic analysis was carried out using Molecular Evolutionary Genetics Analysis (MEGA) software version X [61], following multiple data alignments by CLUSTAL OMEGA [62]. Distances and clustering were determined according to the neighbor-joining and maximum-parsimony methods. Cluster stability was ascertained by bootstrap analysis (1000 replications). The GenBank/EMBL/DDBJ accession number for the $16 \mathrm{~S}$ rRNA sequence of Paenibacillus lutrae $\mathrm{N} 10^{\mathrm{T}}$ is MG831947.

\subsection{G+C Content}

DNA was purified according to Marmur's method [63]. G+C content of Paenibacillus spp. was determined by the thermal denaturalization $\left(\mathrm{T}_{\mathrm{m}}\right)$ method using Escherichia coli NCTC 9001 as control [64].

\subsection{Genome Sequencing and Assembly}

DNA of strain ${\mathrm{N} 10^{\mathrm{T}}}$, previously extracted according to the protocol described by Marmur [63], was sequenced using the Illumina Hi-Seq platform at the STAB VIDA facility (Caparica, Portugal) with $2 \times 150-$ bp paired-end reads. The reads, which were processed by BBDuk (https://sourceforge.net/ projects/bbmap/) to remove adapters and low-quality bases and reads, were then assembled using 
SPAdes software v. 3.11.1 [65] and the contigs were blasted against the $\mathrm{nr} / \mathrm{nt}$ database to remove those contigs belonging to contaminants.

\subsection{In Silico ANI and DDH}

Average nucleotide identity based on BLAST (ANIb) and MUMmer (ANIm) algorithms was determined with the aid of JSpeciesWS software [66], while digital DNA-DNA hybridization (dDDH) was calculated using the BLAST+ algorithm on the DSMZ Genome-to-Genome Distance Calculator (GGDC 2.1) platform [67]. The results presented in this study are based on the recommended Formula 2 (identities/HSP length), which, being independent of genome length, is robustly protected against the use of incomplete draft genomes. OrthoANI was similarly calculated using OrthoANI software [68].

\subsection{Analysis of Multilocus Sequences and Core Orthologous Genes}

A phylogenetic tree was built by aligning the concatenated sequences of the 16S rRNA, gyrB, $r e c A$, and $r p o B$ genes obtained with the aid of CLUSTAL OMEGA [62]. For strain $\mathrm{N} 10^{\mathrm{T}}$, these genes were extracted from the annotation made with Rapid Annotation Subsystem Technology (RAST) software [69], whereas for the rest of the species, the sequences were obtained from their publicly available genome deposited in NCBI. Finally, the phylogenetic tree was constructed using iQ-TREE 1.6.12 [70] according to the maximum likelihood method, taking into account the partitions of genes and codons [71,72], with Bacillus subtilis subsp. subtilis ATCC $6051^{\mathrm{T}}$ as the outgroup. A core genome analysis of strain $\mathrm{N} 10^{\mathrm{T}}$ and the five closest related bacteria based on their 16s rRNA percentage of similarity for which their genome was available was also performed using Bacterial Pan Genome Analysis (BPGA) software [73] with the default parameters. After obtaining the core of these six bacterial genomes, all protein orthologs belonging to the core genome were concatenated and aligned by MAFFT [74]. A phylogenomic tree of the core genes of the species was then constructed using MEGA X software according to the neighbor-joining method.

\section{Results and Discussion}

\subsection{Phenotypic Characterization}

Given its chitinolytic activity, strain $\mathrm{N} 10^{\mathrm{T}}$ was selected from among the eleven sporulated strains isolated from the river otter feces and then characterized taxonomically. Its colonies on LB medium had a circular (diameter 1.0-2.0 mm) and convex morphology with a brilliant pink pigmentation after $48 \mathrm{~h}$ of incubation. Cells were found to be rod-shaped $(2.2 \times 0.8 \mu \mathrm{m})$, motile by peritrichous flagella and Gram-, catalase- and oxidase-positive. Strain N10 ${ }^{\mathrm{T}}$ was slightly halophilic and produced oval endospores $(1.2 \times 0.8 \mu \mathrm{m})$ in swollen sporangia (Figure 1 ).

Strain $\mathrm{N} 10^{\mathrm{T}}$ was found to be a facultative anaerobe, with no differences between aerobic and anaerobic growth being detected. It grew in a 15 to $37^{\circ} \mathrm{C}$ temperature range, with $28^{\circ} \mathrm{C}$ as optimum, in a $\mathrm{pH}$ range of 7 to 10 , with $8 \mathrm{pH}$ as optimum. The strain, which grew in the presence of $0 \%$ to $3 \%$ $(w / v)$ concentrations of $\mathrm{NaCl}$, with optimum growth at $1 \%(w / v) \mathrm{NaCl}$, was slightly halophilic.

Strain $\mathrm{N} 10^{\mathrm{T}}$ was found to produce $\mathrm{H}_{2} \mathrm{~S}$ from L-cystein; to hydrolyze chitin (Figure 1) and Tween ${ }^{\circledR}$ 20 , but not Tween ${ }^{\circledR} 80$, gelatine, casein, starch, DNA or lecithovitellin; to fix $\mathrm{N}_{2}$; and to degrade 1-aminocyclopropane-1-carboxilic acid (ACC). The tests for methyl red, indole, Voges-Proskauer, citrate, hemolysis, alkaline phosphatase, and aerobic nitrate reduction to nitrite, were negative. Its phenotypic characteristics are shown in Table 1 and the species description section. The differential characteristics of strain $\mathrm{N} 10^{\mathrm{T}}$ with respect to the most closely related species, P. chitinolyticus (LMG $18047^{\mathrm{T}}$ ) and with the type strain of genus P. polymyxa (CECT $155^{\mathrm{T}}$ ) are also shown in Table 1 . The strain $\mathrm{N} 10^{\mathrm{T}}$ mainly differs in relation to the following features: pink coloration of the colonies, the slight requirements of $\mathrm{NaCl}$, the inability to reduce aerobically nitrate, produce acids from glucose and many other sugar compounds and enzymes such as acid phosphatase, $\beta$-galactosidase or $\beta$-glucosidase. 

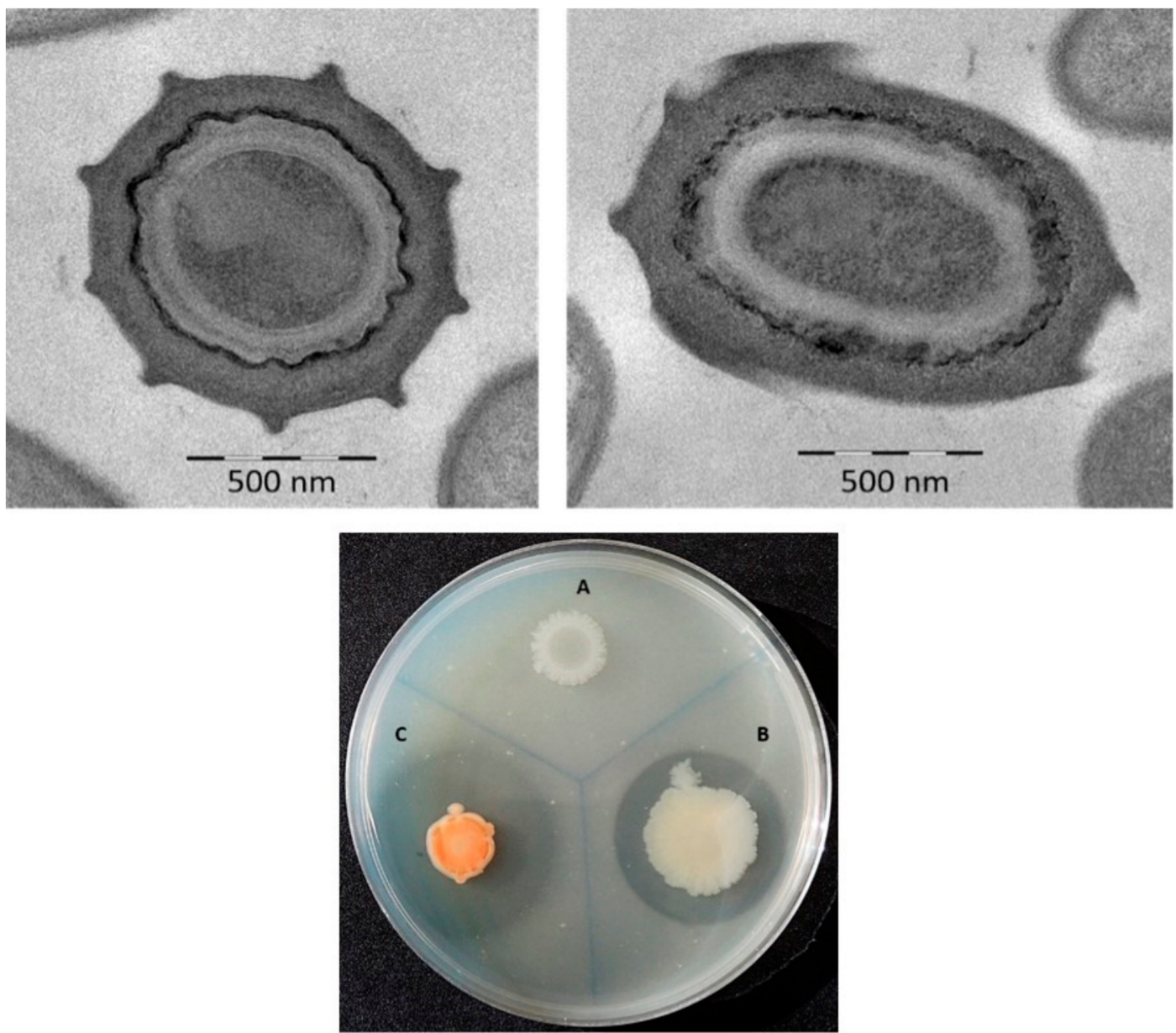

Figure 1. Transmission electron micrographs of oval-shaped endospores of strain $\mathrm{N}^{1} 0^{\mathrm{T}}$ (upper images) and chitinolytic activity (lower image). P. polymyxa CECT $155^{\mathrm{T}}(\mathbf{A})$, P. chitinolitycus LMG $18047^{\mathrm{T}}$ (B), and strain $\mathrm{N} 10^{\mathrm{T}}(\mathbf{C})$ on LB medium supplemented with $1 \%(w / v)$ colloidal chitin.

Table 1. Differential characteristics between $\mathrm{N} 10^{\mathrm{T}}$ strain with respect to its closest relative and the type strain of the genus Paenibacillus.

\begin{tabular}{cccc}
\hline Characteristic & $\mathbf{1}$ & $\mathbf{2}$ & $\mathbf{3}$ \\
\hline Colony Pigmentation & Pink & Cream & Cream-White \\
NaCl range $(\%)(w / v)$ & $0-3$ & $0-4$ & $0-5$ \\
NaCl optimum $(\%)(w / v)$ & 1 & 0 & 0 \\
pH range & $7-10$ & $6-9$ & $6-9$ \\
pH optimum & 8 & 7 & 7 \\
Oxidase & + & $\mathrm{v}$ & - \\
Methyl red & - & - & + \\
Voges-Proskauer & - & - & + \\
Aerobic nitrate reduction & - & + & + \\
Hydrolysis of: & & & - \\
Gelatine & - & $\mathrm{v}$ & - \\
Chitin & + & + & + \\
Starch & - & - & + \\
Casein & - & $\mathrm{v}$ & + \\
Tween 80 & - & - & - \\
ACC deaminase & + & + & + \\
Assimilation of: & - & & + \\
L-arabinose & - & - & \\
D-mannose & - & + & + \\
\hline
\end{tabular}


Table 1. Cont.

\begin{tabular}{|c|c|c|c|}
\hline Characteristic & 1 & 2 & 3 \\
\hline D-mannitol & - & - & + \\
\hline$N$-acetyl-glucosamine & - & + & - \\
\hline $\begin{array}{l}\text { Potassium gluconate } \\
\text { Enzymes: }\end{array}$ & - & + & + \\
\hline Alkaline phosphatase & - & + & - \\
\hline Acid phosphatase & - & + & + \\
\hline$\alpha$-galactosidase & - & - & + \\
\hline$\beta$-galactosidase & - & + & + \\
\hline$\beta$-glucosidase & - & + & + \\
\hline \multicolumn{4}{|l|}{ Acids from carbohydrates: } \\
\hline Glycerol & - & + & + \\
\hline Galactose & - & + & + \\
\hline Manose & - & + & + \\
\hline Amygdaline & - & + & + \\
\hline Arbutin & - & + & + \\
\hline Salicin & - & + & + \\
\hline Cellobiose & - & + & + \\
\hline Lactose & - & + & + \\
\hline Melibiose & - & + & + \\
\hline Sucrose & - & + & + \\
\hline Trehalose & - & + & + \\
\hline Gentiobiose & - & + & + \\
\hline D-turanose & - & + & + \\
\hline \multicolumn{4}{|l|}{ Antimicrobial susceptibility: } \\
\hline Ampicilin & $S$ & I & $S$ \\
\hline Cloramphenicol & $S$ & $\mathrm{I}$ & $S$ \\
\hline Kanamycin & $\mathrm{R}$ & $\mathrm{R}$ & $S$ \\
\hline Nalidixic acid & $S$ & $\mathrm{R}$ & $S$ \\
\hline Rifampicin & S & S & $\mathrm{R}$ \\
\hline Trimethoprim/sulfamethoxazole & $\mathrm{R}$ & S & S \\
\hline DNA G + C content $(\mathrm{Tm})(\mathrm{mol} \%)$ & $45-48$ & $51-53$ & $43-46$ \\
\hline DNA G $+C$ content (in silico) ( $\mathrm{mol} \%)$ & 49.8 & 52.4 & 45.5 \\
\hline
\end{tabular}

Strains: 1 , N10 $0^{\mathrm{T}}$ strain; 2, P. chitinolitycus LMG $18047^{\mathrm{T}} ; 3$, P. polymyxa CECT $155^{\mathrm{T}}$. +, positive; -, negative; $\mathrm{v}$, variable; $\mathrm{S}$, susceptible; I, intermediate; $\mathrm{R}$, resistant. All strains were rods, Gram-positive, growth in anaerobic conditions and produce oval spores. All data shown in this table derive from this study. All strains were negative for indole, citrate, cellulase, DNase, lecithinase, hemolysis, and siderophore production and did not grow on MacConkey agar, but were positive for catalase, $\mathrm{H}_{2} \mathrm{~S}$ production, nitrogen-fixing and Tween ${ }^{\circledR} 20$ hydrolysis. The three strains analyzed were negative for arginine dihydrolase (ADH), urease, gelatinase, capric acid, malic acid, adipic acid and phenylacetic acid assimilations, C14 lipase, leucine arylamidase, valine arylamidase, cysteine arylamidase, trypsin, $\alpha$-chymotrypsin, $\beta$-glucuronidase, $N$-acetyl- $\beta$-glucosaminidase, $\alpha$-mannosidase, and $\alpha$-fucosidase. All strains showed positive results for esculin, D-glucose and D-maltose assimilations, C4 and C8 lipases, $\alpha$-glucosidase, and naphthol-AS-BI-phosphohydrolase. All strains were positive for acid production from esculin, glucose, glycogen, D-maltose, 1-methyl- $\alpha$-D-glucopyranoside, starch, and D-ribose. By contrast, they were negative for acid production from D-adonitol, D-arabinose, D- and L-arabitol, dulcitol, erythritol, D- and L-fucose, inositol, 1-methyl- $\alpha$-D-mannopyranoside, potassium gluconate, potassium 2-ketogluconate, and potassium 5-ketogluconate, D-sorbitol, L-sorbose, D-tagatose, xylitol and D- and L-xylose. All strains were sensitive to gentamicin, neomycin, novobiocin, penicillin $\mathrm{G}$, and tetracycline, but were resistant to streptomycin.

\subsection{Phylogenetic Analysis Based on the $16 S$ rRNA Gene Sequence}

Sequencing of the cloned $16 \mathrm{~S}$ rRNA gene of strain $\mathrm{N} 10^{\mathrm{T}}$ resulted in a virtually complete 1520 bp-long sequence. Phylogenetic analysis of the $16 \mathrm{~S}$ rRNA gene sequences of strain N10 ${ }^{\mathrm{T}}$ and other 100 related strains revealed that strain $\mathrm{N}^{1} 0^{\mathrm{T}}$ is a member of the genus Paenibacillus (Figure S1). It showed the highest sequence similarity to P. chitinolyticus LMG $18047^{\mathrm{T}}(95.4 \%)$ and less than $95 \%$ similarity to other species of genus Paenibacillus. The phylogenetic tree constructed using the neighbor-joining algorithm indicates that strain $\mathrm{N} 10^{\mathrm{T}}$ forms a cluster with the P. chitinolyticus species, which showed the highest sequence similarity (Figure 2 and Figure S1). Using maximum-likelihood and maximum-parsimony 
algorithms, the Paenibacillus species was found to have the same phylogenetic distribution (Figures S2 and S3).

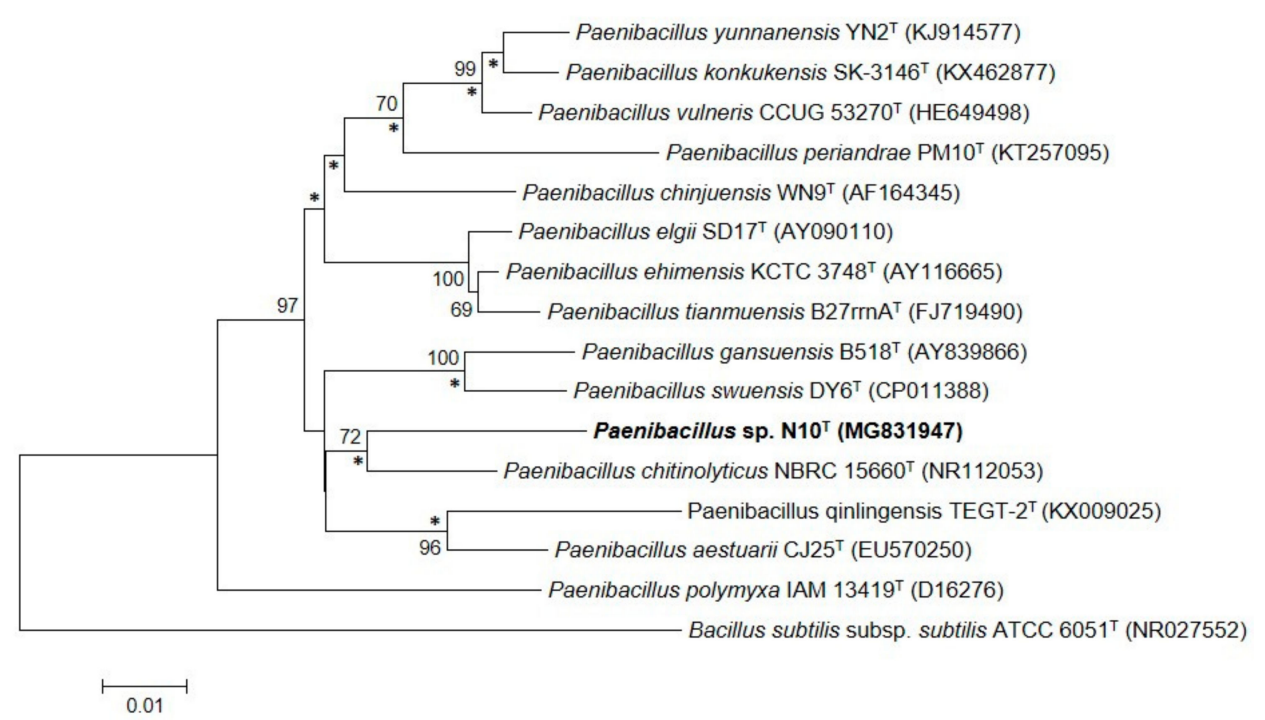

Figure 2. Phylogenetic position of strain $\mathrm{N} 10^{\mathrm{T}}$ based on the neighbor-joining algorithm of the $16 \mathrm{~S}$ rRNA gene sequence and its relationship with other related species. The GenBank/EMBL/DDBJ accession number of each sequence is shown in parenthesis. Bootstrap values are expressed as percentages of 1000 replications, and those greater than $60 \%$ are shown at branch points. Bar shows sequence divergence. Bar, 0.01 substitutions per nucleotide position. Asterisks indicate that the corresponding nodes were also obtained in the trees generated with the maximum-likelihood and maximum-parsimony algorithms.

\subsection{Analysis of Cellular Fatty Acids, Polar Lipids, Isoprenoid Quinones and Peptidoglycan Structure}

The fatty acid profile of strain $\mathrm{N} 10^{\mathrm{T}}$, which showed a predominance of anteiso- $\mathrm{C}_{15: 0}(56.95 \%)$, $\mathrm{C}_{16: 0}(11.69 \%)$, and iso- $\mathrm{C}_{15: 0}(8.46 \%)$, was similar from that of the most closely related strains and the type strain of the genus (Table 2). The major isoprenoid quinone of strain $\mathrm{N} 10^{\mathrm{T}}$ was found to be MK-7, while diphosphatidylglycerols (DPGs), phosphatidylglycerol (PG), phosphatidylethanolamine (PE), and phosphoaminolipids (PNL) were the main polar lipids, features also commonly found in genus Paenibacillus [75]. The results of two-dimensional thin-layer chromatography (TLC) analysis of polar lipids are shown in the Supplementary Materials (Figure S4). The diamino acid of the cell-wall peptidoglycan for $\mathrm{N} 10^{\mathrm{T}}$ strain and P. chitinolyticus LMG $18047^{\mathrm{T}}$ was meso-diamino-pimelic acid (type A1 $\gamma$ ), as found in other members of Paenibacillus genus.

\section{4. $G+C$ Content}

The $\mathrm{G}+\mathrm{C}$ content of strain $\mathrm{N} 10^{\mathrm{T}}$, determined by the melting temperature $\left(T_{m}\right)$ method, was in the $45-48 \mathrm{~mol} \%$ range, while an in silico analysis of its draft genome $\mathrm{G}+\mathrm{C}$ content produced a value of $49.8 \mathrm{~mol} \%$. These percentages fall within the broad 39 to $54 \mathrm{~mol} \%$ range commonly accepted for members of genus Paenibacillus [28].

\subsection{Whole-Genome Sequencing and Assembly}

The over 5.54 Mbp-long draft genome of strain ${\mathrm{N} 10^{\mathrm{T}}}$, after manual curation, resulted in 48 contigs, while the $6.43 \mathrm{Mbp}$-long draft genome of P. chitinolyticus $\mathrm{LMG} 18047^{\mathrm{T}}$ in the public databases contains 32 contigs. After assembling the whole genome of strain $\mathrm{N} 10^{\mathrm{T}}$, the sequence was tested using Quality Assessment Tool for Genome Assemblies (QUAST) software. The results indicate that the whole-genome sequence was of sufficient quality, with an N50 value of 286655, an L50 value of 5, and 380X coverage. PGAP annotation [76] showed a total of 4718 protein-coding genes (PCGs), 3771 of which were assigned to a functional COG category in the EggNOG database [77,78]; categories K 
(transcription) and G (carbohydrate transport and metabolism) were the most abundant, with seven chitinase genes being found in the latter category. Strain N10 ${ }^{\mathrm{T}}$ presented 117 RNAs and $816 \mathrm{~S}$ rRNA gene copies. Nevertheless, only one of them was complete, whereas the rest of the copies corresponded to partial sequences. This genome sequence, which was deposited in the GenBank/EMBL/DDBJ database under accession number RHLK00000000, was used for further analysis.

Table 2. Cellular fatty acids content of $\mathrm{N}^{\mathrm{T}} 0^{\mathrm{T}}$ and related species of the genus. Strains: $1, \mathrm{~N} 10^{\mathrm{T}}$; 2, P. chitinolyticus LMG $18047^{\mathrm{T}}$; 3, P. polymyxa CECT $155^{\mathrm{T}}$. -, not detected or lower than $1 \%$ of total composition.

\begin{tabular}{cccc}
\hline Cellular Fatty Acids & $\mathbf{1}$ & $\mathbf{2}$ & $\mathbf{3}$ \\
\hline Straight-chain fatty acids: & & & \\
$\mathrm{C}_{14: 0}$ & 2.50 & 2.49 & - \\
$\mathrm{C}_{15: 0}$ & 1.17 & - & - \\
$\mathrm{C}_{16: 0}$ & 11.69 & 25.88 & 8.39 \\
Branched-chain fatty acids: & & & \\
iso-c $14: 0$ & 1.86 & - & 3.16 \\
iso-c $15: 0$ & 8.46 & 6.26 & 3.44 \\
anteiso-c $15: 0$ & 56.95 & 49.20 & 47.79 \\
iso-c $16: 0$ & 5.98 & 2.34 & 18.80 \\
iso-c $17: 0$ & 2.63 & 4.73 & 3.38 \\
anteiso-c $17: 0$ & 5.82 & 6.76 & 12.24 \\
Unsaturated fatty acids: & & & \\
C $_{16: 1} \omega 11 \mathrm{c}$ & 1.59 & - & - \\
\hline
\end{tabular}

\subsection{ANI and dDDH Calculations}

The average nucleotide identities (ANIs), based on BLAST (ANIb) and MUMmer (ANIm), for strain $\mathrm{N}^{1} 0^{\mathrm{T}}$ and related Paenibacillus species, are shown in Table S1. The ANIb and ANIm values between strain $\mathrm{N} 10^{\mathrm{T}}$ and the most closely related P. chitinolyticus LMG $18047^{\mathrm{T}}$ were $74.4 \%$ and $84.6 \%$, respectively. In all cases, the ANI values for strain $\mathrm{N} 10^{\mathrm{T}}$ and all species studied were lower than the cut-off for species demarcation (95\%-96\%) proposed by Richter and Rosselló-Móra [79,80]. Although not clear genus delimitation has been elucidated based on ANI values [81], Pérez-Cataluña et al. [74] consider that $68 \%$ could be the genus ANI threshold value. The ANIb between $\mathrm{N}^{\mathrm{T}}{ }^{\mathrm{T}}$ and P. chitinolyticus LMG $18047^{\mathrm{T}}$ is over this value, reinforcing that strain $\mathrm{N} 10^{\mathrm{T}}$ belongs to the Paenibacillus genus. As expected, according to Lee et al. [68], the OrthoANI value between $\mathrm{N} 10^{\mathrm{T}}$ strain and P. chitinolyticus was slightly higher (75.6\%) than the ANIb value (74.4\%) (Table S2).

A comparison of the whole-genome sequences of the species analyzed showed digital DNA-DNA hybridization (dDDH) similarity of less than $32 \%$ (Table S2). The dDDH similarity between strain $\mathrm{N} 10^{\mathrm{T}}$ and P. chitinolyticus $\mathrm{LMG} 18047^{\mathrm{T}}$ was $21.1 \%$, a percentage that supports species delineation, as the established cut-off value for $\mathrm{dDDH}$ is $70 \%$ [82]. This was also the case for $\mathrm{dDDH}$ similarity between $\mathrm{N} 10^{\mathrm{T}}$ and P. polymyxa, and the closest related species P. elgii, P. vulneris and P. qinlingensis, with percentages of $31.4 \%, 19.9 \%, 21.6 \%$ and $19.3 \%$, respectively.

\subsection{Phylogenetic Analysis of Multilocus Sequences and Core Orthologous Proteins}

For a more robust analysis, a phylogenetic tree was built by aligning the concatenated sequences of the $16 \mathrm{~S}$ rRNA and the three housekeeping $g y r B, \operatorname{rec} A$, and $r p o B$ genes resulting in an alignment of $8269 \mathrm{nt}$. The 43 type strains out of the 102 closest species for which these sequences were available and correctly annotated, along with $\mathrm{N} 10^{\mathrm{T}}$ and Bacillus subtilis subsp. subtilis ATCC $6051^{\mathrm{T}}$ as the outgroup, were used for this analysis. The resulting phylogenetic tree constructed according to the maximum likelihood method (Figure 3) confirms that strain $\mathrm{N} 10^{\mathrm{T}}$ belongs to the genus Paenibacillus in accordance with the result obtained in the previous phylogenetic analysis using $16 \mathrm{~S}$ rRNA sequences. The tree was carried out taking into account the partitions and codons of each gene. 


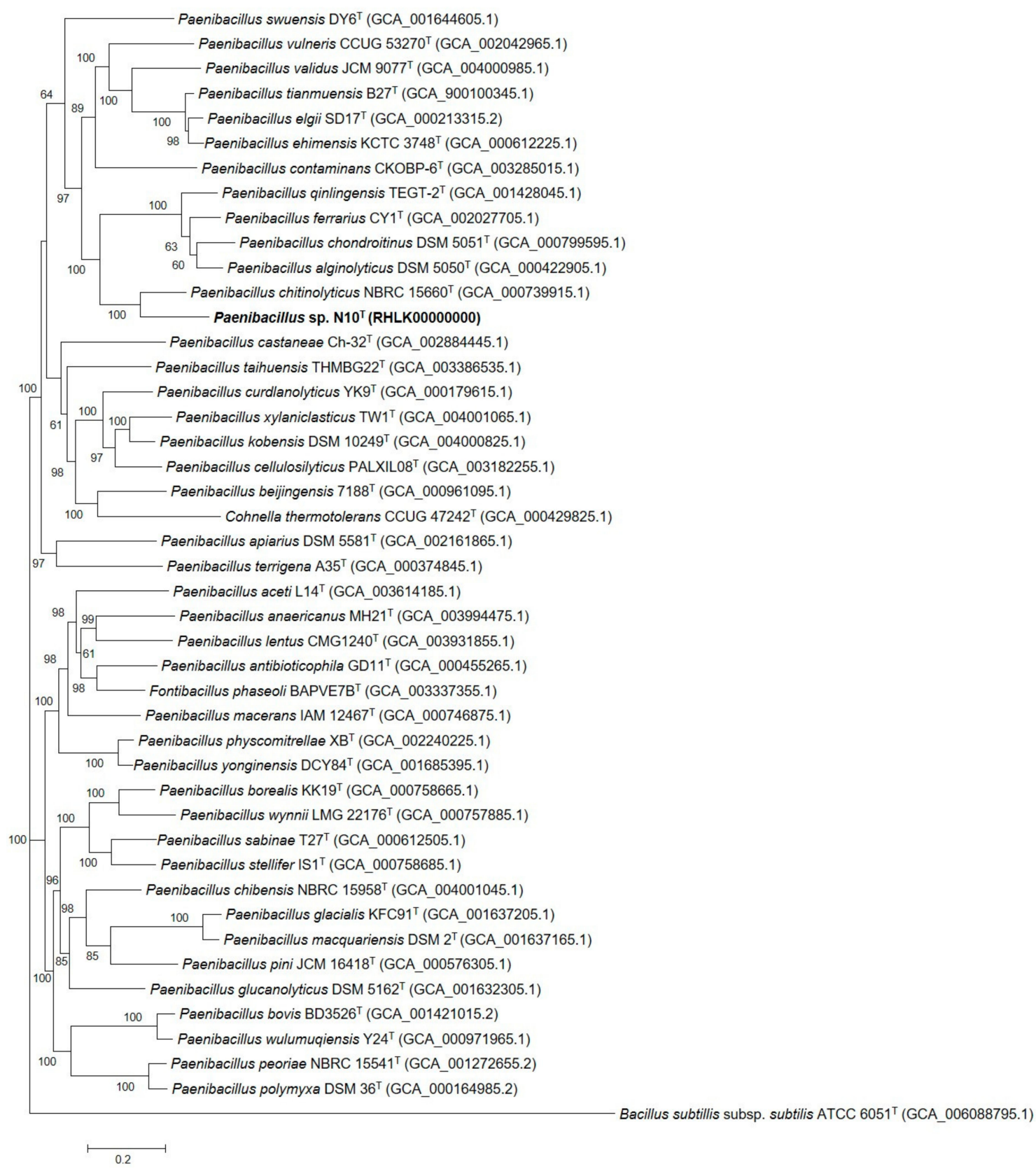

Figure 3. Maximum-likelihood tree based on a comparison of the concatenated $16 \mathrm{~S}$ rRNA, gyrB, $\operatorname{rec} A$, and $r p o B$ gene sequences, showing the phylogenetic position of strain $\mathrm{N} 10^{\mathrm{T}}$ and its relationship with the 43 closely related species of genus Paenibacillus. Bootstrap values are expressed as percentages of 1000 replications, and those greater than $60 \%$ are shown at branch points. Bar, 0.2 substitutions per nucleotide position.

A phylogenetic tree reconstruction based on the concatenated alignment of the 1078 core orthologous proteins confirmed that strain $\mathrm{N} 10^{\mathrm{T}}$ and the five closest related bacteria have the same phylogenetic distribution (Figure 4), thus corroborating our previous results. 


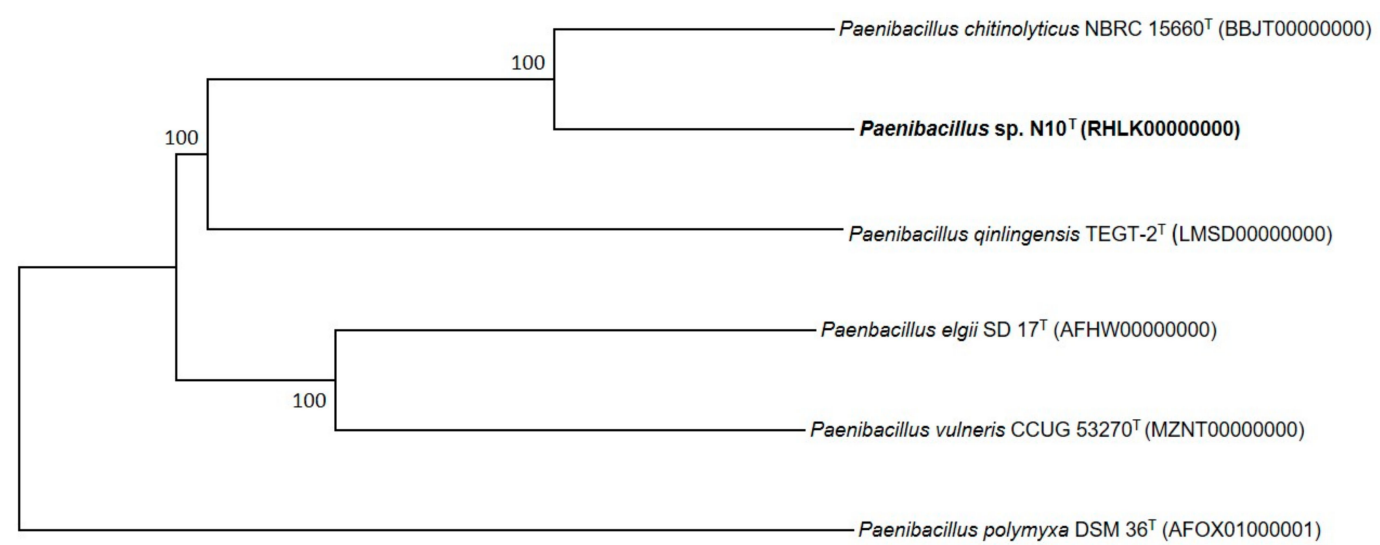

0.050

Figure 4. Tree constructed according to the neighbor-joining method based on 1078 core orthologous proteins of strain $\mathrm{N} 10^{\mathrm{T}}$ and five additional most closely related species of genus Paenibacillus. Bootstrap values are expressed as percentages of 1000 replications, and those over $60 \%$ are shown at branch points. Bar, 0.05 substitutions per nucleotide position.

\section{Conclusions}

The polyphasic taxonomic study, which included a phenotypic and phylogenetic $16 \mathrm{~S}$ rRNA, gyrB, $r e c A$, and $r p o B$ gene analysis, as well as chemotaxonomic and genomic analyses, showed that strain $\mathrm{N} 10^{\mathrm{T}}$ isolated from river otter (L. lutra) feces constitutes a novel species (proposed name: Paenibacillus lutrae sp. nov.) within genus Paenibacillus, with type strain $\mathrm{N} 10^{\mathrm{T}}\left(=\right.$ CECT $9541^{\mathrm{T}}=$ LMG $\left.30535^{\mathrm{T}}\right)$. The description of Paenibacillus lutrae sp. nov. is summarized in Appendix A.

Supplementary Materials: The following are available online at http://www.mdpi.com/2076-2607/7/12/637/s1, Figure S1: Phylogenetic position of strain N10T based on the neighbour-joining algorithm of the 16S rRNA gene sequence and its relationship with other 100 related species. The GenBank/EMBL/DDBJ accession number of each sequence is shown in parenthesis. Bootstrap values are expressed as percentages of 1000 replications, and those greater than $60 \%$ are shown at branch points. Bar shows sequence divergence. Bar, 0.015 substitutions per nucleotide position. Figure S2: Molecular phylogenetic analysis of the 16S rRNA sequence according to the maximum likelihood method. Evolutionary history was inferred using the aforementioned method based on the Jukes-Cantor model. The tree with the highest log likelihood (-5308.40532.87) is shown. Bootstrap values are expressed as percentages of 1000 replications, and those over $60 \%$ are shown at branch points. The Bacillus subtilis subsp. subtilis ATCC $6051^{\mathrm{T}}$ sequence was used as the outgroup. Figure S3: Molecular phylogenetic analysis of the $16 \mathrm{~S}$ rRNA sequence using the maximum parsimony method. The most parsimonious tree (length $=$ $592)$ is shown. The consistency, retention and composite indices are $0.501114,0.554672$ and $0.344796(0.277954)$, respectively, for all sites and parsimony-informative sites (in parentheses). Bootstrap values are expressed as percentages of 1000 replications, and those over $60 \%$ are shown at branch points. The Bacillus subtilis subsp. subtilis ATCC $6051^{\mathrm{T}}$ sequence was used as the outgroup. Figure S4. Polar lipid profile of strain N10 ${ }^{\mathrm{T}}$ determined after two-dimensional TLC using molybdatophosphoric acid. AL: aminolipid; DPG: diphosphatidylglycerol; L: lipid; PE: phosphatidylethanolamine; PG: phosphatidylglycerol; PL: phospholipid; PNL: phosphoaminolipid. Table $\mathrm{S} 1$. ANIb and ANIm (in brackets) values among the genomes of strain N10 ${ }^{\mathrm{T}}(1)$ and the most related species of Paenibacillus genus: P. chitinolyticus LMG18047 ${ }^{\mathrm{T}}$ (2), P. polymyxa CECT155 ${ }^{\mathrm{T}}$ (3), P. elgii SD17 ${ }^{\mathrm{T}}(4)$, P. vulneris CCUG $53270^{\mathrm{T}}(5)$ and P. qinlingensis TEGT-2 ${ }^{\mathrm{T}}(6)$. Table S2. Genome sequence similarity between $\mathrm{N} 10^{\mathrm{T}}$ strain and genome sequences of closely related type strains with available genomes.

Author Contributions: M.R., J.C.R., V.B. and I.L. conceived and supervised the study; V.B. and I.L. designed the experiments; MR performed the experiments; J.C.R. took over genomic analysis; M.R., J.C.R. and I.L. analysed the data, prepared the figures and wrote the manuscript; M.R., J.C.R., V.B. and I.L. edited the manuscript and reviewed the literature.

Funding: This study was supported by a grant from the Spanish Ministerio de Educación y Ciencia (AGL-2015-68806-R) and from the Plan Andaluz de Investigación (Research Group BIO 188). Miguel A. Rodríguez is supported by a University of Granada Programme (Empleo Garantía Juvenil). José C. Reina is supported by an FPU fellowship from the Spanish Ministerio de Educación, Cultura y Deporte (FPU15/01717). 
Acknowledgments: The authors wish to thank Francisco Rodríguez Vicario for providing samples from the Castril Natural Park and Michael O'Shea for proofreading the manuscript.

Conflicts of Interest: The authors declare no conflict of interest.

\section{Appendix A}

Description of Paenibacillus lutrae sp. nov

Paenibacillus lutrae (lu'trae. L. fem. gen. n. lutrae pertaining to the Lutra lutra otter from which the bacterium was isolated).

Paenibacillus lutrae sp. nov. is a motile, straight, Gram-positive, $2.2 \times 0.8 \mu \mathrm{m}$ rod-shaped bacteria which forms oval endospores in swollen sporangia. The colonies of $P$. lutrae on LB medium are a pink color after growing for $48 \mathrm{~h}$ at $28^{\circ} \mathrm{C}$. Cells growth pattern is uniform in a liquid medium. They are capable of growing in the presence of $0 \%$ to $3 \%(w / v) ~ N a C l$ concentrations, with $1 \%(w / v)$ as optimum. The cells grow in a temperature range of 15 to $37^{\circ} \mathrm{C}$, with optimum growth at $28^{\circ} \mathrm{C}$, and a pH range of 7 to 10 , with $\mathrm{pH} 8$ as optimum. P. lutrae is a chemoorganotrophic and anaerobic facultative microorganism. Under aerobic conditions, nitrate is not reduced. Indole and methyl-red tests are negative, and catalase and oxidase are negative. Acids are not produced from adonitol, D-celobiose, D-fructose, D-galactose, myo-inositol, lactose, D-mannitol, D-mannose, D-melezitose, L-rhamnose, sucrose, D-salicilin, D-sorbitol, sorbose or D-trehalose. Tween 20 is hydrolyzed but, starch, casein, lecithovitellin, gelatine, Tween 80 , urea, blood, or phosphates are not. $\mathrm{H}_{2} \mathrm{~S}$ is produced from L-cysteine but not butanediol from glucose (Voges-Proskauer negative). ONPG is negative. No growth occurs on MacConkey agar. They are susceptible to ampicillin $(10 \mu \mathrm{g})$, chloramphenicol $(30 \mu \mathrm{g})$, gentamycin $(10 \mu \mathrm{g})$, neomycin $(30 \mu \mathrm{g})$, novobiocin $(30 \mu \mathrm{g})$, penicillin $\mathrm{G}(10 \mu \mathrm{g})$, nalidixic acid $(30 \mu \mathrm{g})$, rifampicin $(2 \mu \mathrm{g})$ and tetracycline $(30 \mu \mathrm{g})$. They are resistant to streptomycin $(10 \mu \mathrm{g})$, kanamycin $(30 \mu \mathrm{g})$ and trimetroprim/sulphametoxazol $(1.25 / 23.75 \mu \mathrm{g})$.

The principal fatty acids of $P$. lutrae are anteiso- $C_{15: 0}(56.95 \%), C_{16: 0}(11.69 \%)$, and iso- $C_{15: 0}(8.46 \%)$, and the main isoprenoid quinone is MK-7. The principal polar lipids are diphosphatidylglycerols (DPGs), phosphatidylglycerol (PG), phosphatidylethanolamine (PE), and phosphoaminolipids (PNL). The diamino acid of the cell-wall peptidoglycan was meso-diamino-pimelic acid (type A1 $\gamma$ ). DNA $\mathrm{G}+\mathrm{C}$ content was in the $45-48 \mathrm{~mol} \%$ range according to the $T_{m}$ method and $49.8 \mathrm{~mol} \%$ according to in silico determination.

Type strain N10 ${ }^{\mathrm{T}}\left(=\mathrm{CECT} 9541^{\mathrm{T}}=\mathrm{LMG} 30535^{\mathrm{T}}\right)$ was isolated from the feces of a river otter in Castril Natural Park in Granada (Spain).

The GenBank/EMBL/DDBJ accession number for the 16S rRNA sequence of Paenibacillus lutrae $\mathrm{N} 10^{\mathrm{T}}$ is MG831947, and the complete genome is deposited under the accession number RHLK00000000.

\section{References}

1. Flach, J.; Pilet, P.-E.; Jollès, P. What's new in chitinase research? Experientia 1992, 48, 701-716. [CrossRef] [PubMed]

2. Kramer, K.J.; Muthukrishnan, S. Insect chitinases: Molecular biology and potential use as biopesticides. Insect Biochem. Mol. Biol. 1997, 27, 887-900. [CrossRef]

3. Gooday, G.W. Diversity of roles for chitinases in nature. In Chitin and Chitosan-The Versatile Environmentally Friendly Modern Materials; Zakaria, M.B., Muda, W.M.W., Abdullah, M.P., Eds.; Penerbit Universiti Kebangsaan Malasya: Bangi, Malasia, 1995; Volume 3, pp. 191-202.

4. Cottrell, M.T.; Kirchman, D.L. Natural assemblages of marine proteobacteria and members of the Cytophaga-Flavobacter cluster consuming low-and high-molecular-weight dissolved organic matter. Appl. Environ. Microbiol. 2000, 66, 1692-1697. [CrossRef] [PubMed]

5. Beier, S.; Bertilsson, S. Uncoupling of chitinase activity and uptake of hydrolysis products in freshwater bacterioplankton. Limnol. Oceanogr. 2011, 56, 1179-1188. [CrossRef] 
6. Reyes-Ramírez, A.; Escudero-Abarca, B.; Aguilar-Uscanga, G.; Hayward-Jones, P.; Barboza-Corona, J.E. Antifungal activity of Bacillus thuringiensis chitinase and its potential for the biocontrol of phytopathogenic fungi in soybean seeds. J. Food Sci. 2004, 69, M131-M134. [CrossRef]

7. Huang, C.J.; Wang, T.K.; Chung, S.C.; Chen, C.Y. Identification of an antifungal chitinase from a potential biocontrol agent, Bacillus cereus 28-9. J. Biochem. Mol. Biol. 2005, 38, 82-88. [CrossRef] [PubMed]

8. Aktuganov, G.E.; Melent'ev, A.I.; Galimzyanova, N.F.; Shirokov, A.V. The study of mycolytic properties of aerobic spore-forming bacteria producing extracellular chitinases. Microbiology 2008, 77, 700-709. [CrossRef]

9. Singh, A.K.; Ghodke, I.; Chhatpar, H.S. Pesticide tolerance of Paenibacillus sp. D1 and its chitinase. J. Environ. Manag. 2009, 91, 358-362. [CrossRef]

10. Terahara, T.; Ikeda, S.; Noritake, C.; Minamisawa, K.; Ando, K.; Tsuneda, S.; Harayama, S. Molecular diversity of bacterial chitinases in arable soils and the effects of environmental factors on the chitinolytic bacterial community. Soil Biol. Biochem. 2009, 41, 473-480. [CrossRef]

11. Brzezinska, M.S.; Donderski, W. Chitinolytic bacteria in two lakes of different trophic status. Pol. J. Ecol. 2006, 54, 295-301.

12. Haas, D.; Défago, G. Biological control of soil-borne pathogens by fluorescent pseudomonads. Nat. Rev. Microbiol. 2005, 3, 307-319. [CrossRef] [PubMed]

13. Someya, N.; Ikeda, S.; Morohoshi, T.; Tsujimoto, M.N.; Yoshida, T.; Sawada, H.; Ikeda, T.; Tsuchiya, K. Diversity of culturable chitinolytic bacteria from rhizospheres of agronomic plants in Japan. Microbes Environ. 2009, 26, 7-14. [CrossRef] [PubMed]

14. Spiegel, Y.; Chet, I.; Cohn, E. Use of chitin for controlling plant plant-parasitic nematodes. Plant Soil 1987, 98, 337-345. [CrossRef]

15. Vionis, A.P.; Niemeyer, F.; Karagouni, A.D.; Schrempf, H. Production and processing of a 59-kilodalton exochitinase during growth of Streptomyces lividans carrying pCHIO12 in soil microcosms amended with crab or fungal chitin. Appl. Environ. Microbiol. 1996, 62, 1774-1780.

16. Williamson, N.; Brian, P.; Wellington, E. Molecular detection of bacterial and streptomycete chitinases in the environment. Antonie Van Leeuwenhoek 2000, 78, 315-321. [CrossRef]

17. Gomes, R.C.; Semêdo, L.T.; Soares, R.M.; Alviano, C.S.; Linhares, L.F.; Coelho, R.R. Chitinolytic activity of actinomycetes from a cerrado soil and their potential in biocontrol. Lett. Appl. Microbiol. 2000, 30, 146-150. [CrossRef]

18. Gomes, R.; Semêdo, L.; Soares, R.; Linhares, L.; Ulhoa, C.; Alviano, C.; Coelho, R. Purification of a thermostable endochitinase from Streptomyces RC1071 isolated from a cerrado soil and its antagonism against phytopathogenic fungi. J. Appl. Microbiol. 2001, 90, 653-661. [CrossRef]

19. Yasir, M.; Aslam, Z.; Kim, S.W.; Lee, S.W.; Jeon, C.O.; Chung, Y.R. Bacterial community composition and chitinase gene diversity of vermicompost with antifungal activity. Bioresour. Technol. 2009, 100, 4396-4403. [CrossRef]

20. Cottrell, M.T.; Moore, J.A.; Kirchman, D.L. Chitinases from uncultured marine microorganisms. Appl. Environ. Microbiol. 1999, 65, 2553-2557.

21. Beier, S.; Jones, C.M.; Mohit, V.; Hallin, S.; Bertilsson, S. Global phylogeography of chitinase genes in aquatic metagenomes. Appl. Environ. Microbiol. 2011, 77, 1101-1106. [CrossRef]

22. Eski, A.; Demir, I.; Gullu, M.; Demirbag, Z. Biodiversity and pathogenicity of bacteria associated with the gut microbiota of beet armyworm, Spodoptera exigua Hübner (Lepidoptera: Noctuidae). Microb. Pathog. 2018, 121, 350-358. [CrossRef] [PubMed]

23. Pasari, N.; Gupta, M.; Eqbal, D.; Yazdani, S.S. Genome analysis of Paenibacillus polymyxa A18 gives insights into the features associated with its adaptation to the termite gut environment. Sci. Rep. 2019, 9, 6091. [CrossRef] [PubMed]

24. Beygmoradi, A.; Homaei, A. Marine chitinolytic enzymes, a biotechnological treasure hidden in the ocean? Appl. Microbiol. Biotechnol. 2018, 102, 9937-9948. [CrossRef] [PubMed]

25. Chen, L.; Wei, Y.; Shi, M.; Li, Z.; Zhang, S.-H. An archaeal chitinase with a secondary capacity for catalyzing cellulose and its biotechnological applications in shell and straw degradation. Front. Microbiol. 2019, 10, 1253. [CrossRef]

26. Chen, Q.; Peng, D. Nematode chitin and application. Adv. Exp. Med. Biol. 2019, 1142, 209-219. [CrossRef] 
27. Zhou, J.; Chen, J.; Xu, N.; Zhang, A.; Chen, K.; Xin, F.; Zhang, W.; Ma, J.; Fang, Y.; Jiang, M.; et al. The broad-specificity chitinases: Their origin, characterization, and potential application. Appl. Microbiol. Biotechnol. 2019, 103, 3289-3295. [CrossRef]

28. Ash, C.; Priest, F.G.; Collins, M.D. Molecular identification of rRNA group 3 bacilli (Ash, Farrow, Wallbanks and Collins) using a PCR probe test. Antonie van Leeuwenhoek 1993, 64, 253-260. [CrossRef]

29. Djukic, M.; Becker, D.; Poehlein, A.; Voget, S.; Daniel, R. Genome sequence of Paenibacillus alvei DSM 29, a secondary invader during European foulbrood outbreaks. J. Bacteriol. 2012, 194, 6365. [CrossRef]

30. Kuroshima, K.-I.; Sakane, T.; Takata, R.; Yokota, A. Bacillus ehimensis sp. nov. and Bacillus chitinolyticus sp. nov., new chitinolytic members of the genus Bacillus. Int. J. Syst. Evol. Microbiol. 1996, 46, 76-80. [CrossRef]

31. Lee, J.S.; Pyun, Y.R.; Bae, K.S. Transfer of Bacillus ehimensis and Bacillus chitinolyticus to the genus Paenibacillus with emended descriptions of Paenibacillus ehimensis comb. nov. and Paenibacillus chitinolyticus comb. nov. Int. J. Syst. Evol. Microbiol. 2004, 54, 929-933. [CrossRef]

32. Sun, H.; Mao, X. Discovery and characterization of a novel chitosanase from Paenibacillus dendritiformis by phylogeny-based enzymatic product specificity prediction. J. Agric. Food Chem. 2018, 66, 4645-4651. [CrossRef] [PubMed]

33. Kim, Y.H.; Park, S.K.; Hur, J.Y.; Kim, Y.C. Purification and characterization of a major extracellular chitinase from a biocontrol bacterium, Paenibacillus elgii HOA73. Plant. Pathol. J. 2017, 33, 318-328. [CrossRef]

34. García-González, E.; Poppinga, L.; Fünfhaus, A.; Hertlein, G.; Hedtke, K.; Jakubowska, A.; Genersch, E. Paenibacillus larvae chitin-degrading protein PlCBP49 is a key virulence factor in American Foulbrood of honey bees. PLoS Pathog. 2014, 10, e1004284. [CrossRef] [PubMed]

35. Chung, Y.R.; Kim, C.H.; Hwang, I.; Chun, J. Paenibacillus koreensis sp. nov., a new species that produces an iturin-like antifungal compound. Int. J. Syst. Evol. Microbiol. 2000, 50, 1495-1500. [CrossRef]

36. Doan, C.T.; Tran, T.N.; Nguyen, V.B. Reclamation of marine chitinous materials for chitosanase production via microbial conversion by Paenibacillus macerans. Mar. Drugs 2018, 16, 429. [CrossRef] [PubMed]

37. Doan, C.T.; Tran, T.N.; Nguyen, V.B. Production of a thermostable chitosanase from shrimp heads via Paenibacillus mucilaginosus TKU032 conversion and its application in the preparation of bioactive chitosan oligosaccharides. Mar. Drugs 2019, 17, 217. [CrossRef] [PubMed]

38. Passera, A.; Marcolungo, L.; Casati, P. Hybrid genome assembly and annotation of Paenibacillus pasadenensis strain R16 reveals insights on endophytic life style and antifungal activity. PLoS ONE 2018, 13, e0189993. [CrossRef]

39. Cody, R.M. Distribution of chitinase and chitobiase in Bacillus. Curr. Microbiol. 1989, 19, 201-205. [CrossRef]

40. Yahiaoui, M.; Laribi-Habchi, H.; Bouacem, K.; Asmani, K.L.; Mechri, S.; Harir, M.; Bendif, H.; Aissani-El Fertas, R.; Jaouadi, B. Purification and biochemical characterization of a new organic solvent-tolerant chitinase from Paenibacillus timonensis strain LK-DZ15 isolated from the Djurdjura Mountains in Kabylia, Algeria. Carbohydr. Res. 2019, 483, 107747. [CrossRef]

41. Liao, W.; Liu, P.; Liao, W.; Miao, L. Complete genome of the chitin-degrading bacterium, Paenibacillus xylanilyticus W4. Genome Biol. Evol. 2019, 11, 3252-3255. [CrossRef]

42. An, C.; Okamoto, Y.; Xu, S.; Eo, K.Y.; Kimura, J.; Yamamoto, N. Comparison of fecal microbiota of three captive carnivore species inhabiting Korea. J. Vet. Med. Sci. 2017, 79, 542-546. [CrossRef] [PubMed]

43. Logan, N.A.; Berge, O.; Bishop, A.H.; Busse, H.-J.; De Vos, P.; Fritze, D.; Heyndrickx, M.; Kämpfer, P.; Rabinovitch, L.; Salkinoja-Salonen, M.S.; et al. Proposed minimal standards for describing new taxa of aerobic, endospore-forming bacteria. Int. J. Syst. Evol. Microbiol. 2009, 59, 2114-2121. [CrossRef] [PubMed]

44. Kovacs, N. Identification of Pseudomonas pyocyanea by the oxidase reaction. Nature 1956, 178, 703. [CrossRef] [PubMed]

45. Xie, Q.Y.; Lin, H.P.; Li, L.; Brown, R.; Goodfellow, M.; Deng, Z.; Hong, K. Verrucosispora wenchangensis sp. nov., isolated from mangrove soil. Antonie Van Leeuwenhoek 2012, 102, 1-7. [CrossRef] [PubMed]

46. Clarke, P.H. Hydrogen sulphide production by bacteria. J. Gen. Microbiol. 1953, 8, 397-407. [CrossRef] [PubMed]

47. Skerman, V.B.D. A Guide to the Identification of the Genera of Bacteria; The Williams \& Wilkins, Co.: Baltimore, MD, USA, 1961; p. 251.

48. Kovacs, N. Eine vereinfachte methode zum nachweis der indolbildung durch bakterien. Immunforsch 1928, $55,311-315$. 
49. Barritt, M.M. The intensification of the Voges-Proskauer reaction by the addition of $\alpha$-naphthol. J. Pathol. Bacteriol. 1936, 42, 441-454. [CrossRef]

50. Uttley, A.; Collins, C. Theory and practice of bacterial identification. In Cowan and Steel's Manual for the Identification of Medical Bacteria, 3rd ed.; Barrow, G.I., Feltham, R.K.A., Eds.; Cambridge University Press: Cambridge, UK, 1993; pp. 46-49.

51. Matthews, S.; Suhaimi, M. Selection of suitable growth medium for free-living diazotrophs isolated from compost. J. Trop. Agric. Food Sci. 2010, 38, 211-219.

52. Poonguzhali, S.; Madhaiyan, M.; Sa, T. Cultivation-dependent characterization of rhizobacterial communities from field grown Chinese cabbage Brassica campestris ssp. pekinensis and screening of traits for potential plant growth promotion. Plant Soil 2006, 286, 167-180. [CrossRef]

53. Alexander, D.B.; Zuberer, D.A. Use of chrome azurol S reagents to evaluate siderophore production by rhizosphere bacteria. Biol. Fert. Soils 1991, 12, 39-45. [CrossRef]

54. Bauer, A.W.; Kirby, W.M.; Sherris, J.C.; Turck, M. Antibiotic susceptibility testing by a standardized single disk method. Am. J. Clin. Pathol. 1966, 45, 493-496. [CrossRef] [PubMed]

55. Tindall, B.J.; Sikorski, J.; Smibert, R.A.; Krieg, N.R. Phenotypic characterization and the principles of comparative systematics. In Methods for General and Molecular Microbiology, 3rd ed.; Reddy, C., Beveridge, T., Breznak, J., Marzluf, G., Schmidt, T., Snyder, L.A., Eds.; ASM Press: Washington, DC, USA, 2007; pp. 330-393.

56. Tindall, B.J. A comparative study of the lipid composition of Halobacterium saccharovorum from various sources. Syst. Appl. Microbiol. 1990, 13, 128-130. [CrossRef]

57. Tindall, B.J. Lipid composition of Halobacterium lacusprofundi. FEMS Microbiol. Lett. 1990, 66, $199-202$. [CrossRef]

58. Schumann, P. Peptidoglycan structure. Method. Microbiol. 2011, 38, 101-129. [CrossRef]

59. Altschul, S.F.; Gish, W.; Miller, W.; Myers, E.W.; Lipman, D.J. Basic local alignment search tool. J. Mol. Biol. 1990, 215, 403-410. [CrossRef]

60. Yoon, S.H.; Ha, S.M.; Kwon, S.; Lim, J.; Kim, Y.; Seo, H.; Chun, J. Introducing EzBioCloud: A taxonomically united database of 16S rRNA gene sequences and whole-genome assemblies. Int. J. Syst. Evol. Microbiol. 2017, 67, 1613-1617. [CrossRef]

61. Kumar, S.; Stecher, G.; Li, M.; Knyaz, C.; Tamura, K. MEGA X: Molecular Evolutionary Genetics Analysis across Computing Platforms. Mol. Biol. Evol. 2018, 35, 1547-1549. [CrossRef]

62. Sievers, F.; Wilm, A.; Dineen, D.; Gibson, T.J.; Karplus, K.; Li, W.; López, R.; McWilliam, H.; Remmert, M.; Soding, J.; et al. Fast, scalable generation of high-quality protein multiple sequence alignments using Clustal Omega. Mol. Syst. Biol. 2011, 7, 539. [CrossRef]

63. Marmur, J. A procedure for the isolation of deoxyribonucleic acid from micro-organisms. J. Mol. Biol. 1961, 3, 208-218. [CrossRef]

64. Owen, R.; Pitcher, D. Current methods for estimating DNA base composition and levels of DNA-DNA hybridization. In Chemicals Methods in Bacterial Systematics; Goodfellow, M., Minnikin, D.E., Eds.; Academic Press: London, UK, 1985; Volume 20, pp. 67-93.

65. Nurk, S.; Bankevich, A.; Antipov, D.; Gurevich, A.A.; Korobeynikov, A.; Lapidus, A.; Prjibelski, A.D.; Pyshkin, A.; Sirotkin, A.; Sirotkin, Y.; et al. Assembling single-cell genomes and mini-metagenomes from chimeric MDA products. J. Comput. Biol. 2013, 20, 714-737. [CrossRef]

66. Richter, M.; Rosselló-Móra, R.; Oliver Glöckner, F.; Peplies, J. JSpeciesWS: A web server for prokaryotic species circumscription based on pairwise genome comparison. Bioinformatics 2015, 32, 929-931. [CrossRef] [PubMed]

67. Meier-Kolthoff, J.P.; Auch, A.F.; Klenk, H.P.; Göker, M. Genome sequence-based species delimitation with confidence intervals and improved distance functions. BMC Bioinform. 2013, 14, 60. [CrossRef]

68. Lee, I.; Kim, Y.O.; Park, S.C.; Chun, J. OrthoANI: An improved algorithm and software for calculating average nucleotide identity. Int. J. Syst. Evol. Microbiol. 2016, 66, 1100-1103. [CrossRef] [PubMed]

69. Aziz, R.K.; Bartels, D.; Best, A.A.; DeJongh, M.; Disz, T.; Edwards, R.A.; Formsma, K.; Gerdes, S.; Glass, E.M.; Kubal, M.; et al. The RAST Server: Rapid annotations using subsystems technology. BMC Genom. 2008, 9, 75. [CrossRef] [PubMed]

70. Nguyen, L.T.; Schmidt, H.A.; von Haeseler, A.; Minh, B.Q. IQ-TREE: A fast and effective stochastic algorithm for estimating maximum-likelihood phylogenies. Mol. Biol. Evol. 2015, 32, 268-274. [CrossRef] 
71. Chernomor, O.; von Haeseler, A.; Minh, B.Q. Terrace aware data structure for phylogenomic inference from supermatrices. Syst. Biol. 2016, 65, 997-1008. [CrossRef]

72. Kainer, D.; Lanfear, R. The effects of partitioning on phylogenetic inference. Mol. Biol. Evol. 2015, 32, 1611-1627. [CrossRef]

73. Chaudhari, N.M.; Gupta, V.K.; Dutta, C. BPGA-an ultra-fast pan-genome analysis pipeline. Sci. Rep. 2016, 6, 24373. [CrossRef]

74. Katoh, K.; Standley, D.M. MAFFT multiple sequence alignment software version 7: Improvements in performance and usability. Mol. Biol. Evol. 2013, 30, 772-780. [CrossRef]

75. Yao, R.; Wang, R.; Wang, D.; Su, J.; Zheng, S.; Wang, G. Paenibacillus selenitireducens sp. nov., a selenite-reducing bacterium isolated from a selenium mineral soil. Int. J. Syst. Evol. Microbiol. 2014, 64, 805-811. [CrossRef]

76. Tatusova, T.; DiCuccio, M.; Badretdin, A.; Chetvernin, V.; Nawrocki, E.P.; Zaslavsky, L.; Lomsadze, A.; Pruitt, K.D.; Borodovsky, M.; Ostell, J. NCBI prokaryotic genome annotation pipeline. Nucleic Acids Res. 2016, 44, 6614-6624. [CrossRef] [PubMed]

77. Huerta-Cepas, J.; Szklarczyk, D.; Forslund, K.; Cook, H.; Heller, D.; Walter, M.C.; Rattei, T.; Mende, D.R.; Sunagawa, S.; Kuhn, M.; et al. eggNOG 4.5: A hierarchical orthology framework with improved functional annotations for eukaryotic, prokaryotic and viral sequences. Nucleic Acids Res. 2016, 44, D286-D293. [CrossRef] [PubMed]

78. Huerta-Cepas, J.; Forslund, K.; Coelho, L.P.; Szklarczyk, D.; Jensen, L.J.; von Mering, C.; Bork, P. Fast genome-wide functional annotation through orthology assignment by eggNOG-Mapper. Mol. Biol. Evol. 2017, 34, 2115-2122. [CrossRef] [PubMed]

79. Richter, M.; Rosselló-Móra, R. Shifting the genomic gold standard for the prokaryotic species definition. Proc. Natl. Acad. Sci. USA 2009, 106, 19126-19131. [CrossRef]

80. Kim, M.; Oh, H.S.; Park, S.C.; Chun, J. Towards a taxonomic coherence between average nucleotide identity and 16S rRNA gene sequence similarity for species demarcation of prokaryotes. Int. J. Syst. Evol. Microbiol. 2014, 64, 346-351. [CrossRef]

81. Pérez-Cataluña, A.; Salas-Massó, N.; Diéguez, A.L.; Balboa, S.; Lema, A.; Romalde, J.L.; Figueras, M.J. Revisiting the taxonomy of the genus Arcobacter: Getting order from the chaos. Front. Microbiol. 2018, 9, 2077. [CrossRef] [PubMed]

82. Goris, J.; Konstantinidis, K.T.; Klappenbach, J.A.; Coenye, T.; Vandamme, P.; Tiedje, J.M. DNA-DNA hybridization values and their relationship to whole-genome sequence similarities. Int. J. Syst. Evol. Microbiol. 2007, 57, 81-91. [CrossRef] 